\title{
Phenotypic Virulence Characterization of Dichelobacter nodosus from the Cases of Ovine Footrot in Andhra Pradesh and Telangana states of India
}

\author{
S. Vijayalakshmi ${ }^{\text {* }}$, D. Sreenivasulu ${ }^{2}$, D. Raniprameela ${ }^{3}$, \\ N. Vinodkumar ${ }^{4}$ and A. Karthik ${ }^{5}$ \\ ${ }^{1}$ LRS, Palamaneru, SVVU, India \\ ${ }^{2}$ SVVU, Tirupati, India \\ ${ }^{3} S L D L, S V V U$, Tirupati, India \\ ${ }^{4}$ Department of Microbiology, CVSc, Tirupati, India \\ ${ }^{5}$ SRF, SLDL, Tirupati, India \\ *Corresponding author
}

\section{A B S T R A C T}

\begin{tabular}{l} 
Ke y w o r d s \\
$\begin{array}{l}\text { Interdigital } \\
\text { epidermis, }\end{array}$ \\
$\begin{array}{l}\text { Economic loss, } \\
\text { RNA gene }\end{array}$ \\
Article Info \\
$\begin{array}{l}\text { Accepted: } \\
21 \text { May } 2020 \\
\text { Available Online: } \\
\text { 10 June } 2020\end{array}$ \\
\hline
\end{tabular}

Footrot is a contagious disease affecting the interdigital epidermis and living tissues of digits of sheep and goats. The disease is being reported in Andhra Pradesh (AP) and Telangana states of India regularly causing significant economic loss to the sheep husbandry. The causative agent is the anaerobic, gram negative bacteria, Dichelobacter nodosus. A total of sixteen isolates of D.nodosus have been recovered from footrot positive clinical samples collected from AP and Telangana state and further confirmed by PCR targeting 16Sr RNA gene. The isolates were further processed for virulence characterization by Gelatin gel test and elastase test. Gelatin gel test revealed $56.5 \%$ of isolates as virulent, $31.25 \%$ of isolates as Intermediate and $12.25 \%$ of isolates as benign. Whereas elastase test identified only $18.75 \%$ of isolates as virulent, $12.5 \%$ of isolates as intermediate, $12.5 \%$ of isolates as benign, the rest $56.25 \%$ of the isolates did not exhibit any elastase activity.

\section{Introduction}

Footrot is highly contagious disease of sheep and goats caused by an obligatory anaerobic bacteria Dichelobacter nodosus. Ovine footrot in India was reported for the first time in India by Wani et al., 2004. Virulence of the D.nodosus is an important factor in developing clinical footrot disease in sheep and goats. Therefore it was important to establish knowledge of virulence of the D.nodosus and the corresponding manifestations of footrot. D.nodosus were categorized as virulent, intermediate and benign based on the corresponding clinical forms of the disease (Stewart et al., 1989).

Sometimes the clinical diagnosis of virulent footrot is not easy, particularly in the early stages of an outbreak, or during hot dry 
conditions when footrot cannot express fully. Therefore laboratory tests like elastase and gelatin gel tests which measures protease activities have been developed to confirm the clinical diagnosis. Dichelobacter nodosus produces different types of proteases like gelatinase, elastase fibrogenase, collagenase and caesinase (Kortt et al., 1994). The degree of virulence of various D.nodosus strains are mainly due to differences in expression of the subtilisin-like extracellular proteases AprV2/ B2, AprV5/B5 and BprV/B (Stauble et al., 2014). Among them the expression of two proteases known as virulent AprV2 and AprB2 was found to fully correlate with the clinical status clinical status. The elastase test measures the quantitative activity of proteases, while the gelatin gel test measures a difference in protease thermostability between the strains of D.nodosus (Liu and Yong, 1993; Palmer 1993). Thermostable strains retain their ability to hydrolyze gelatin even after heating at $68^{\circ} \mathrm{C}$ for $16 \mathrm{~min}$ where as benign strains produced proteases that are susceptible to heat and did not retain gelatinase activity (Palmer 1993). The gelatin gel test has the advantage of being a more rapid test. It takes 2-3 days for testing of protease activity. Whereas, the elastase test requires 21 days to study elastase activity (Links and Morris, 1996). The aim of the study is to characterize D.nodosus isolates with respect to virulence. In the present investigation gelatin test and elastase test were used to study the virulence of D.nodosus isolates recovered in the study.

\section{Materials and Methods}

\section{Collection of samples}

A total of 338 foot swabs were collected from 13 villages of Chittoor, Nellore, Praksam and Mehaboobnagar districts of Andhra Pradesh and Telangana state from sheep with foot lesions (Fig. 1 and 2).
Material from foot lesions were collected aseptically from individual hooves using sterile cotton swabs and inoculated on Trypticase arginine serine (TAS) agar with $4 \%$ hoof powder. The samples were processed for isolation and identification of Dichelobacter nodosus.

\section{Preparation of TAS agar}

TAS agar comprising Trypticase Peptone-1.5 $\mathrm{g}$, Protease Peptone $0.5 \mathrm{~g}$ Beefextract-0.5g, Yeast extract-0.2g, Magnesium sulphate$0.2 \mathrm{~g}$, BactoAgar $-3.0 \mathrm{~g}$. Hoof powder was added at the rate of $4 \%$ and $2 \%$ for preparation of primary isolation and maintenance media respectively was prepared. Then medium was autoclaved at $15 \mathrm{lb}$ pressure for 15 minutes. After autoclaving, it was allowed to cool and 50X serine arginine solution were added at the rate of $2.5 \mathrm{ml}$ per $100 \mathrm{ml}$ of agar. and dispersed into sterile Petri plates and subjected to sterility test before usage.

\section{Preparation of 50x arginine serine solution}

Serine-3.75 g and Arginine - $12.50 \mathrm{~g}$ were weighed and added to $50 \mathrm{ml}$ of sterile triple distilled water and mixed until dissolved. Then the solution was sterilized by $0.2 \mu$ Millipore filter and stored at $-20^{\circ} \mathrm{C}$ for further use.

\section{Inoculation into TAS}

Samples collected from footrot clinical lesions were inoculated on to $4 \%$ Hoofagar plates. These plates were placed in an anaerobic jar (Oxoid) with gaspacks (BD, difco) and incubated at $37^{\circ} \mathrm{C}$. After five days of incubation, suspected colonies were sub cultured on the $2 \%$ Hoofagar plates. The presence of D.nodosus in the colonies was confirmed by PCR targeting $16 \mathrm{~S} r$ RNA. 


\section{Polymerase chain reaction for detection of D. nodosus}

DNA from the suspected colonies of D.nodosus was extracted by boiling method. PCR for detection of 16SrRNA gene of D.nodosus was carried out as per the method of Wani et al., (2004, 2007). Details of the primer sequence are enlisted in Table 1.

PCR amplification was performed in $200 \mu \mathrm{l}$ PCR tubes with a reaction mixture $25 \mu 1$ comprising 10x Taq buffer A- 2.5 $\mu 1,10 \mathrm{mM}$ dNTP mix - $2 \mu \mathrm{l}, \mathrm{MgCl}_{2} 25 \mathrm{~mm}-1.5 \mu \mathrm{l}$, Taq DNA polymerase $(3 \mathrm{U} / \mu \mathrm{l})-0.3 \mu \mathrm{l}$, Forward Primer (10pico moles)- 0.25 1 , Reverse Primer(10picomoles)-0.25 $\mu 1$, DNA Template- $2 \mu 1$, DEPC water $16.25 \mu 1$.

The tubes were then spun for 10 seconds and PCR was carried out in Thermal cycler (Kyratec) with Cycling conditions of intial denaturation at $94^{\circ} \mathrm{C}$ for $2 \mathrm{~min}$, five cycles of denaturation for $30 \mathrm{sec}$ at $94{ }^{\circ} \mathrm{C}$, annealing for $30 \mathrm{sec}$ at $62^{\circ} \mathrm{C}$ and extension at $72^{\circ} \mathrm{C}$ for $4 \mathrm{~m}$, 25 cycles of denaturation for $30 \mathrm{sec}$ at $94{ }^{\circ} \mathrm{C}$, annealing for $30 \mathrm{sec}$ at $62^{\circ} \mathrm{C}$ and extension at $72^{\circ} \mathrm{C}$ for $30 \mathrm{sec}$ and final extension at $72^{\circ} \mathrm{C}$ for $4 \mathrm{~min}$. The JKS-02 strain maintained and characterized in the department was used as positive control.

\section{Detection of $D$. nodosus sero group by multiplex PCR}

The positive samples for Dichelobacter nodosus revealed by the amplification of 16SrRNA gene were subjected to multiplex PCR for serogrouping using serogroup specific primers (Table 2) with a common forward and nine different reverse primers. Method of DNA extraction, enzymes, buffers and PCR conditions used in the test were similar to that of PCR for detection of 16SrRNA except an increased concentration of Forward primer (2.5 times) than reverse primer used in the study.

\section{Agarose gel electrophoresis of PCR} product in $2 \%$ agarose

Amplified products were analyzed by agarose gel electrophoresis. under U.V transilluminator and photographed with Gel Documentation System (Alpha Innotech, AlphaImager HP).

\section{Virulence characterization of $D$. nodosus isolates}

\section{Gelatin gel test}

The gelatin gel test was carried out as per the method developed by Palmer (1993) based on the principle that extracellular proteases produced by virulent strains of $D$. nodosus are more heat stable than those produced by benign strains. Briefly D. nodosus isolates were grown in TAS broth separately for 2-4 days to achieve a concentration of $1 \mathrm{X} 10^{8}$ cells $/ \mathrm{ml}$, measured by spectrophotometric reading.

$500 \mu 1$ of this broth cultures was diluted with 2 $\mathrm{ml}$ of Hepes buffer, mixed well and an aliquots of $20 \mu \mathrm{l}$ was placed into the one of the three wells of an agarose gel containing gelatin in a petriplates. The remaining quantity in dilution was incubated at $68^{\circ} \mathrm{C}$ for $8 \mathrm{~min}$ in water bath and aliquot comprising $20 \mu 1$ was placed in second well.

The sample was further incubated for $8 \mathrm{~min}$ at $68^{\circ} \mathrm{C}$ and $20 \mu \mathrm{l}$ of it placed into the last well. The gels were incubated overnight in a moist chamber at $37^{0} \mathrm{C}$, after which undigested gelatin was precipitated by flooding with hot $\left(60^{\circ}-70^{\circ} \mathrm{C}\right)$ saturated ammonium sulphate solution. The zone of proteolysis indicated by clearing around the wells was measured by scale and recorded in nearest millimeters. 
The percentage of thermostabilty was calculated as

$\%$ Thermo stability $=\frac{\text { Zone size of broth culture heated at } 67^{\circ} \mathrm{C} \text { for } 16 \mathrm{~min}}{\text { Zone size of broth culture unheated }} \times 100$

All the 16 isolates in the study were subjected to Gelatin gel test and the results are recorded.

\section{Elastase test}

The elastase activity of D.nodosus isolates was measured by Elastin agar test as described by stewart (1979). Isolates were cultured in TAS agar with $2 \%$ hoof powder before inoculation in elastin agar comprising Trypticase peptone $-1.5 \mathrm{~g}$, Protease peptone $0.5 \mathrm{~g}$, Beef extract - $0.5 \mathrm{~g}$, Yeastextract $-0.2 \mathrm{~g}$, L-arginine $\mathrm{HCl}-0.5 \mathrm{~g}, \quad$ DLserine- $0.15 \mathrm{~g}$ $\mathrm{MgSO}_{4} .7 \mathrm{H}_{2} \mathrm{O}-0.2 \mathrm{~g}$, Calcium chloride (anhydrous) -0.15 g, Bacto agar (Difco) -1.5 g, Elastin powder (bovine neck ligament, insoluble, Sigma)-0.3 g. All the reagents except the Bacto agar and the elastin powder are dissolved in $100 \mathrm{ml}$ of DW in a sterile conical flask containing a magnetic bar.

The $\mathrm{pH}$ was adjusted to 7.8-8.0 by adding 10 $\mathrm{M} \mathrm{NaOH}$. Agar and elastin powders are dissolved while stirring on a magnetic stirrer until (about 30min) the elastin is well dispersed. Then the medium was autoclaved for 20 minutes at $121^{\circ} \mathrm{C}$ and Cooled to $50^{\circ} \mathrm{C}$. The solution was thoroughly mixed to evenly disperse the elastin particles. The medium is poured aseptically into sterile petridishes and stored in an anaerobic atmosphere at $4^{\circ} \mathrm{C}$.

\section{Inoculation}

An elastase agar plate was marked into tridents. A loopful of culture was streaked in a line about $2-3 \mathrm{~cm}$ in the middle of each trident and similarly the other two tridents with positive and negative controls.
Plates are incubated in an anaerobic jar with as gas pack at $37^{\circ} \mathrm{C}$. Plates were examined on $7^{\text {th }}$ day, $14^{\text {th }}$ day, $21^{\text {st }}$ day and $28^{\text {th }}$ day.

\section{Results and Discussion}

\section{Isolation of Dichelobacter nodosus}

The 4\% hoof agar plates inoculated with suspected foot swab material, incubated under anaerobic conditions at $37^{\circ} \mathrm{C}$ for seven days showed the multiple colonies along the line of streaking. D.nodosus colonies mixed with others were identified based on the colony morphology which has diffuse ground glass appearance particularly around the colony edge and grow out and away from streak line (Fig. 3). A total of eight isolates have been isolated in the study. The smears made out of the pure colonies revealed the presence of gram negative rod shaped, slightly curved organisms with terminal swollen ends characteristic of D.nodosus (Fig. 4). Along with this eight isolates, six isolates (Serogroup 'I'-4, Serogroup 'A'-1 and Serogroup ' $C$ '-1) which were already isolated previously were used in the study. A positive control JKS-20 serogroup 'B', SUKAST was also used in the study

\section{Detection and serorouping of D.nodosus by 16SrRNA PCR}

The DNA extracted from all the eight isolates revealed specific amplicons of $783 \mathrm{bp}$ size (Fig. 5) suggestive of D.nodosus infection. The samples positive by 16SrDNA PCR were subjected to Multiplex PCR. Out of 8 isolates, five isolates revealed specific amplicons of 283 bp size suggestive of ' $B$ ' serogroup (Fig. 6) (Nellore-3 and Mehaboobnagar-2) and three isolates revealed specific amplicons of 189 bp size suggestive of 'I' serogroup (Fig. 7) (Chittoor-3). The eight isolates along with seven isolates (Seroogroup 'B'-1, Serogroup 'I'-4, Serogroup 'A'-1 and Serogroup 'C'-1) 
which were already isolated previously were used in the study.

Protease thermostability test (Gelatin gel test)

The thermo stability of proteases from the isolates was calculated by dividing the zone size of TAS broth culture heated $67^{\circ} \mathrm{C}$ for 16 min by that of unheated control $(0 \mathrm{~min})$. The diameter of the zone of clearance around each well was measured in nearest millimeters. The isolates with percentage of thermo stability between 0 and $10 \%$ were considered as benign, those between $11-60 \%$ as intermediate and those above $60 \%$ are considered as virulent. The results were depicted in table 3. Out of 15 isolates tested for gelatin gel test, 8 isolates were found to be virulent with $\%$ thermostability $>60,5$ isolates were found to be intermediate with \% thermostability 11-60 and two isolates were found benign with $\%$ thermostability $<10$ (Fig. 8).

\section{Elastase test}

Out of 15 isolates tested two isoltes JKS-02 and Bon I were found to degrade elastin within seven days and are considered as virulent. Che-I and Mon-I degraded elastin in 7-14 days and are considered as intermediate, where as the Ard-I, Yplm-I degraded elastin in 14-21 days and are considered as benign and the rest of isolates did not show in elastase activity. The results are shown in Table 4 and Fig. 9.

Table.1 Primer sequence used for detection of 16SrRNA gene

\begin{tabular}{|l|l|c|c|c|}
\hline Primer & Primer sequence (5'-3') & $\begin{array}{c}\text { Target } \\
\text { gene }\end{array}$ & Reference & $\begin{array}{c}\text { Product } \\
\text { size (bp) }\end{array}$ \\
\hline Forward & CGGGGTTATGTAGCTTGC & 16S r RNA & $\begin{array}{c}\text { LA Fontaine, } \\
\text { etal.,(1993) }\end{array}$ & 783 \\
\hline Reverse & $\begin{array}{l}\text { TCGGTACCGAGTATTTCT } \\
\text { ACCCAACACCT }\end{array}$ & & & \\
\hline
\end{tabular}

Table.2 Primer sequence for detection of serogroups of D.nodosus targeting fim- $A$ gene

\begin{tabular}{|c|c|c|c|c|}
\hline Primer & Primer sequence $\left(5^{\prime}-3^{\prime}\right)$ & $\begin{array}{l}\text { Sero- } \\
\text { group }\end{array}$ & $\begin{array}{l}\text { Product } \\
\text { size (bp) }\end{array}$ & Reference \\
\hline Forward primer & CCTTAATCGAACTCATGATTG & & & \multirow{10}{*}{$\begin{array}{c}\text { Dhungyel } \\
\text { et al., } \\
\text { (2002) }\end{array}$} \\
\hline Reverse Primer - A & AGTTTCGCCTTCATTATATTT & $\mathrm{A}$ & 415 & \\
\hline Reverse Primer - B & CGGATCGCCAGCTTCTGTCTT & B & 283 & \\
\hline Reverse Primer - C & AGAAGTGCCTTTGCCGTATTC & $\mathrm{C}$ & 325 & \\
\hline Reverse Primer - D & TGCAACAATATTTCCCTCATC & $\mathrm{D}$ & 390 & \\
\hline Reverse Primer -E & CACTTTGGTATCGATCAACTTGG & $\mathrm{E}$ & 363 & \\
\hline Reverse Primer - F & ACTGATTTCGGCTAGACC & $\mathrm{F}$ & 241 & \\
\hline Reverse rimer - G & CTTAGGGGTAAGTCCTGCAAG & $\mathrm{G}$ & 279 & \\
\hline Reverse primer $-\mathbf{H}$ & TGAGCAAGACCAAGTAGC & $\mathrm{H}$ & 409 & \\
\hline Reverse Primer - I & CGATGGGTCAGCATCTGGACC & $\mathbf{I}$ & 189 & \\
\hline
\end{tabular}


Table.3 Details of D.nodosus isolates showing virulence activity on Gelatin gel test

\begin{tabular}{|c|c|c|c|c|c|c|c|}
\hline \multirow[t]{2}{*}{ S.No } & \multirow[t]{2}{*}{ Isolate } & \multirow{2}{*}{$\begin{array}{l}\text { Unheated } \\
\text { (zone of } \\
\text { clearance } \\
\text { mm) }\end{array}$} & \multicolumn{2}{|c|}{ Heated (8min) } & \multicolumn{2}{|c|}{ Heated (16min) } & \multirow[t]{2}{*}{ Virulence } \\
\hline & & & $\begin{array}{l}\text { Zone of } \\
\text { clearence }\end{array}$ & $\begin{array}{c}\% \text { Thermo } \\
\text { stability }\end{array}$ & $\begin{array}{l}\text { Zone of } \\
\text { clearance }\end{array}$ & $\begin{array}{c}\% \text { Thermo } \\
\text { stability }\end{array}$ & \\
\hline 1 & JKS-B & 21 & 18 & $86 \%$ & 15 & $75 \%$ & Virulent \\
\hline 2 & Ard I-B & 18 & 15 & $83 \%$ & 12 & $67 \%$ & Virulent \\
\hline 3 & Ard II-B & 14 & 8 & $57 \%$ & 6 & $43 \%$ & Intermediate \\
\hline 4 & $\begin{array}{l}\text { MBNR- } \\
\text { B }\end{array}$ & 16 & 9 & $56 \%$ & 7 & $44 \%$ & Intermediate \\
\hline 5 & Bon I-B & 22 & 18 & $82 \%$ & 15 & $68 \%$ & Virulent \\
\hline 6 & Bon II-B & 15 & 5 & $33 \%$ & 1 & $6 \%$ & Benign \\
\hline 7 & Vpet-I & 16 & 8 & $50 \%$ & 5 & $31 \%$ & Intermediate \\
\hline 8 & SKHT-I & 15 & 5 & $33 \%$ & 1.5 & $10 \%$ & Benign \\
\hline 9 & Cha-I & 18 & 14 & $78 \%$ & 12 & $67 \%$ & virulent \\
\hline 10 & Man-I & 17 & 11 & $65 \%$ & 9 & $53 \%$ & Intermediate \\
\hline 11 & PNP-I & 18 & 11 & $61 \%$ & 8 & $44 \%$ & Intermediate \\
\hline 12 & Yplm-I & 21 & 17 & $81 \%$ & 15 & $71 \%$ & Virulent \\
\hline 13 & Bplm-I & 22 & 18 & $82 \%$ & 15 & $68 \%$ & Virulent \\
\hline 14 & Man-A & 23 & 21 & $91 \%$ & 18 & $78 \%$ & Virulent \\
\hline 15 & Man-C & 21 & 18 & $86 \%$ & 15 & $71 \%$ & Virulent \\
\hline
\end{tabular}

Table.4 Results of Elastase test

\begin{tabular}{|c|c|c|c|c|c|}
\hline S.No & Isolate & \multicolumn{3}{|c|}{ Elastase activity } & No elastase \\
activity
\end{tabular}


Int.J.Curr.Microbiol.App.Sci (2020) 9(6): 2924-2936

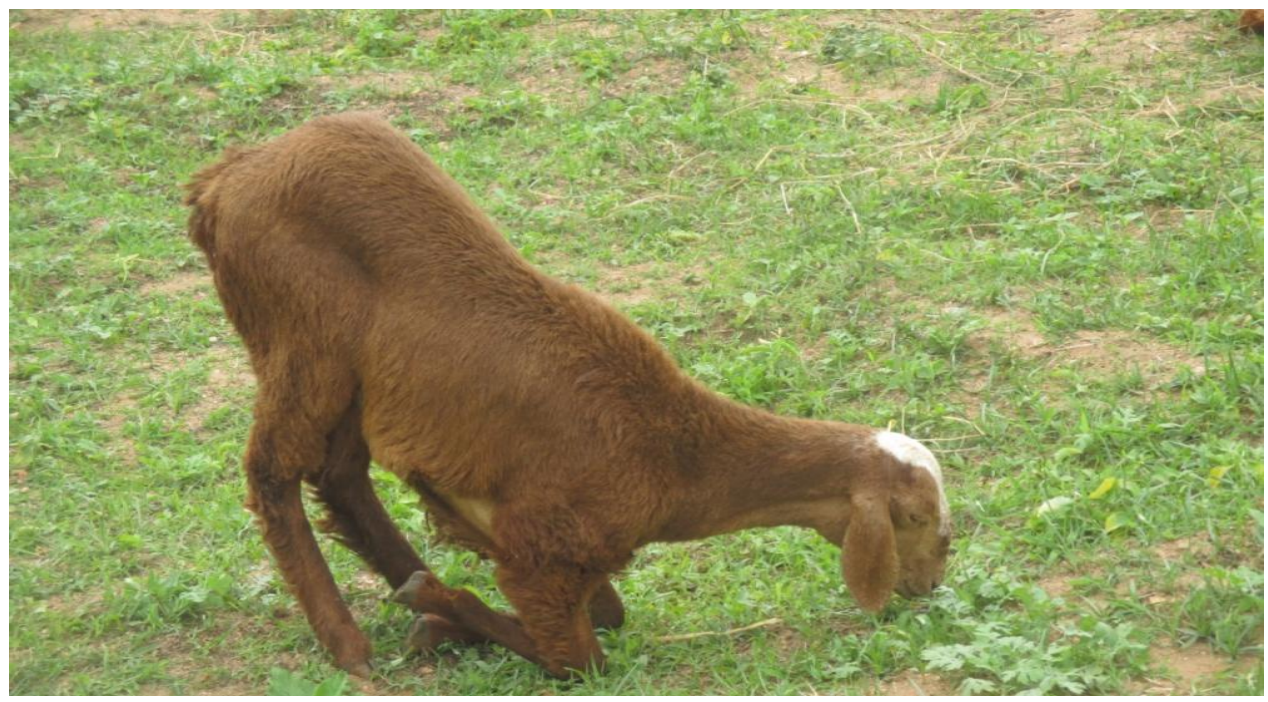

Fig.1 Sheep showing typical lameness

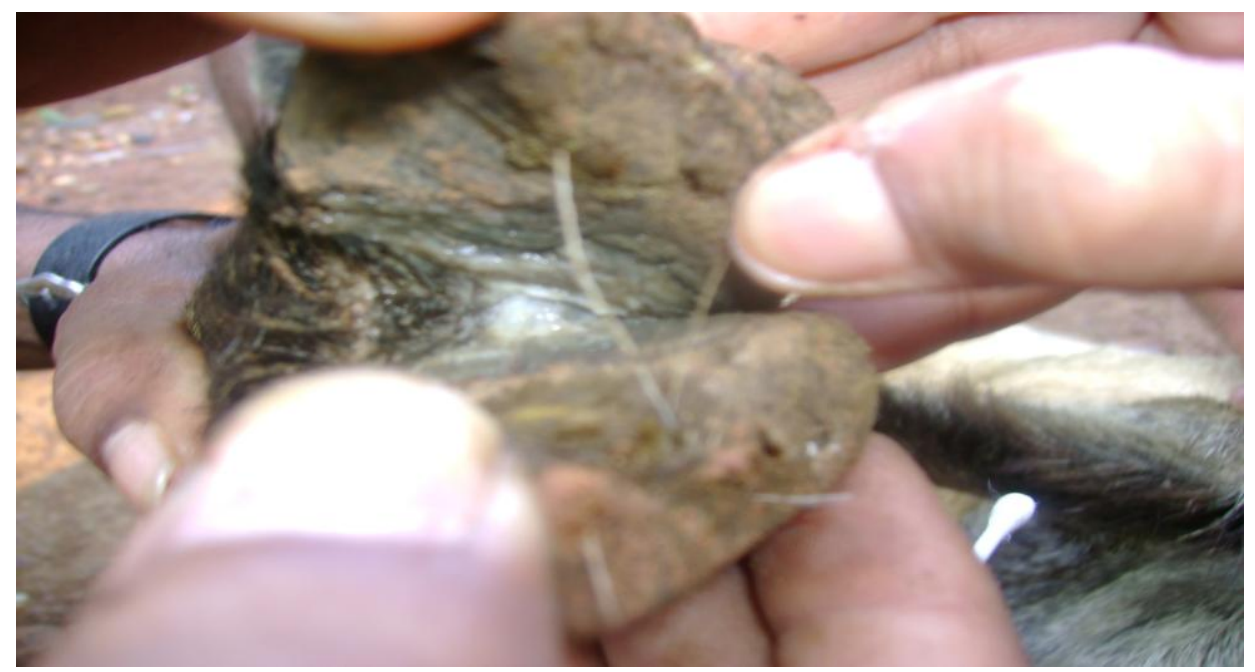

Fig.2 Hoof showing severe lesion of virulent footrot

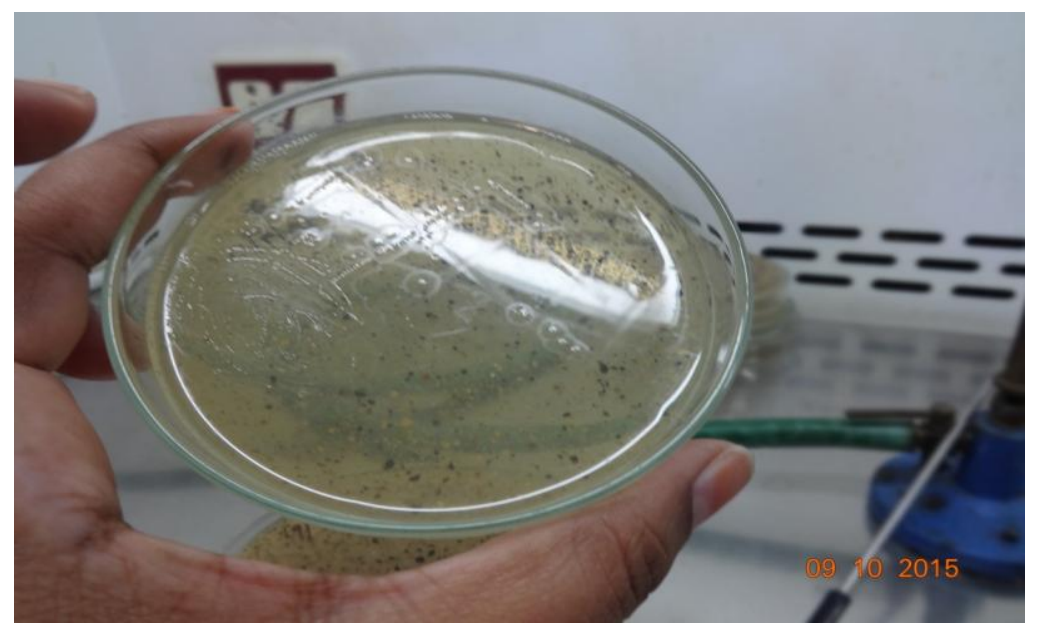

Fig.3 Pure colonies of D.nodosus in 2\% Hoofagar 


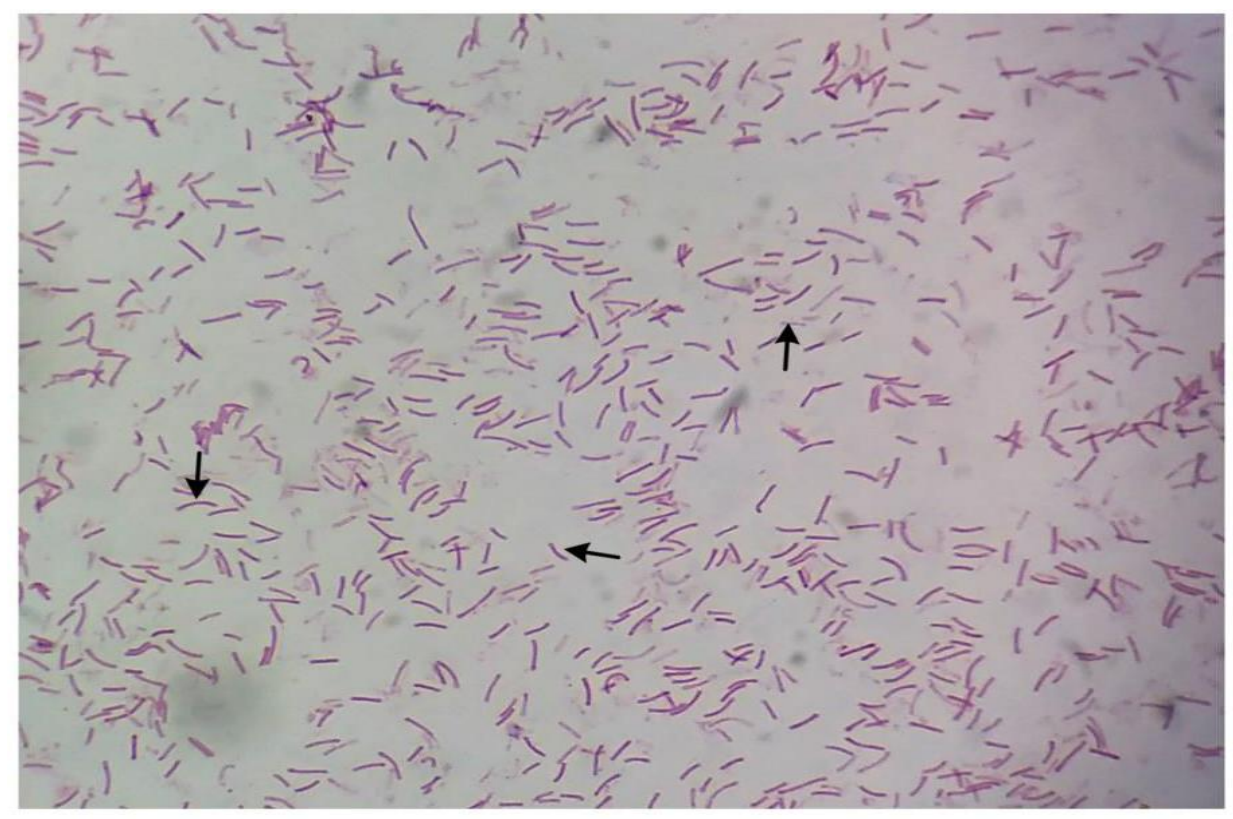

\section{Arrow heads showing Large gram negative curved rods with swollen ends}

Fig.4 Gram staining of D.nodosus

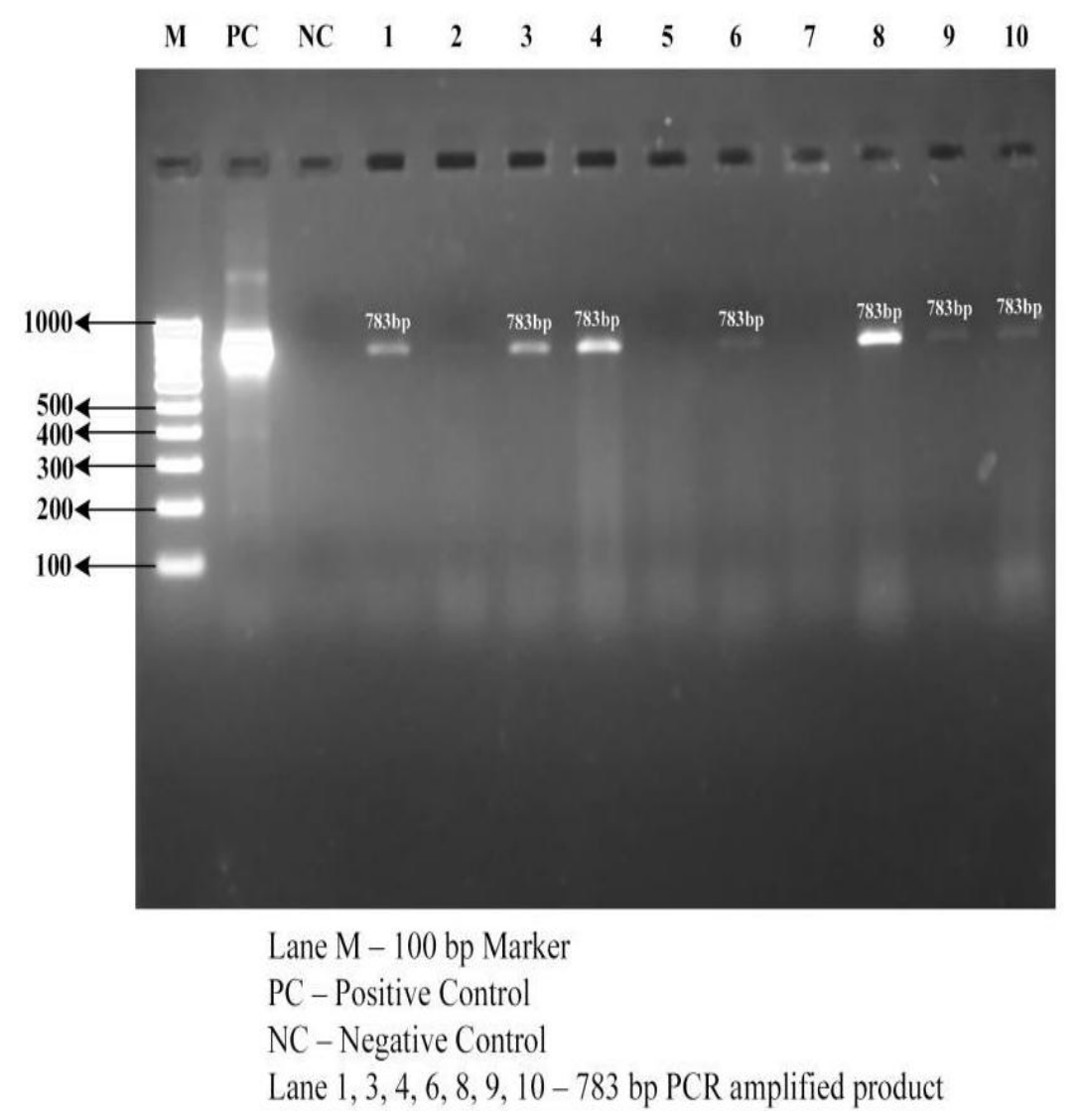

Fig.5 Amplification of 16SrRNA gene of D.nodosus 
Int.J.Curr.Microbiol.App.Sci (2020) 9(6): 2924-2936

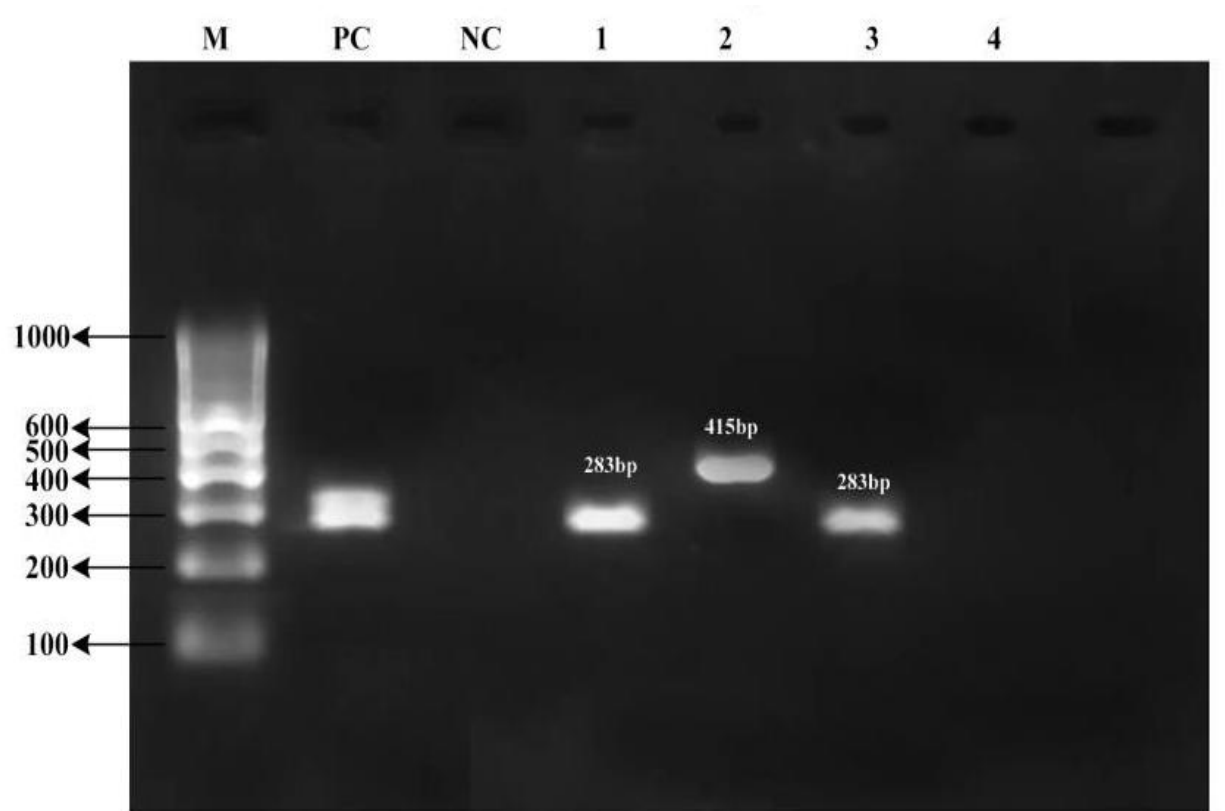

Lane M - 100 bp Marker

PC - Positive Control

$\mathrm{NC}$ - Negative Control

Lane 1, 3-283 bp 'B' serogroup

Lane 2 - 415 bp 'A' serogroup

Fig.6 Serogroup 'B' and 'A' specific PCR products of D.nodosus

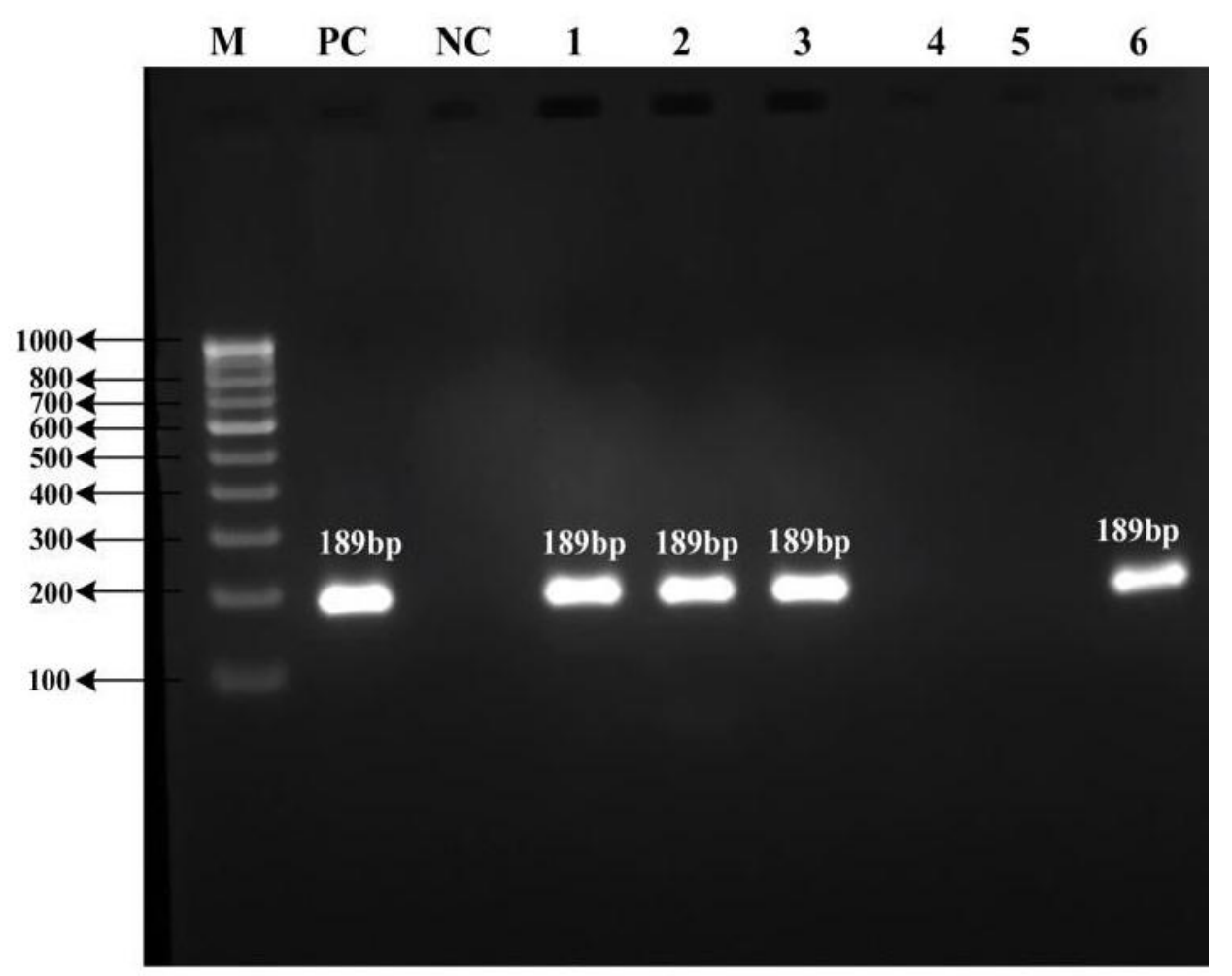

Fig.7 Serogroup 'I' specific PCR products of D.nodosus 


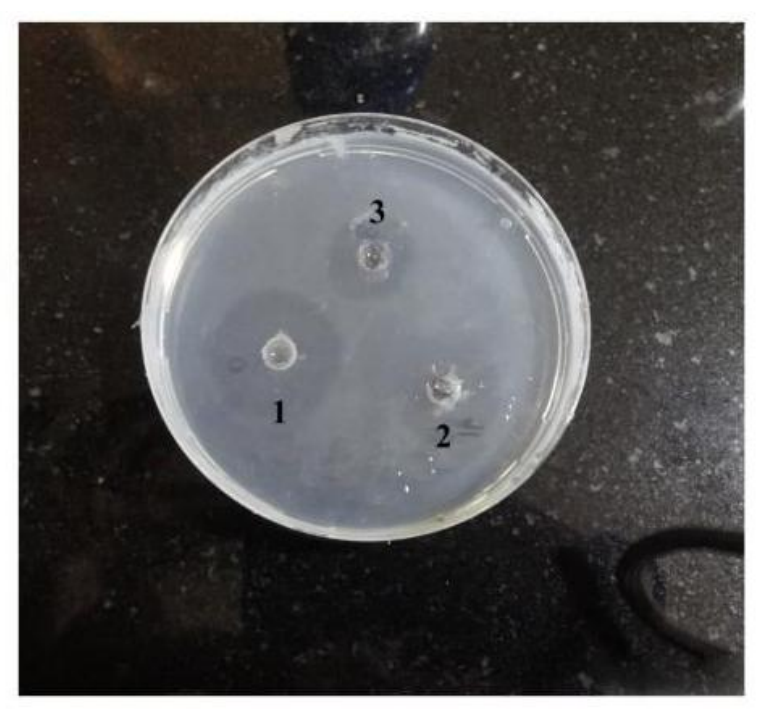

Clearance Zone of TAS broth cultures

1- Unheated

2- Heated for $8 \mathrm{~min}$

3- Heated for $16 \mathrm{~min}$

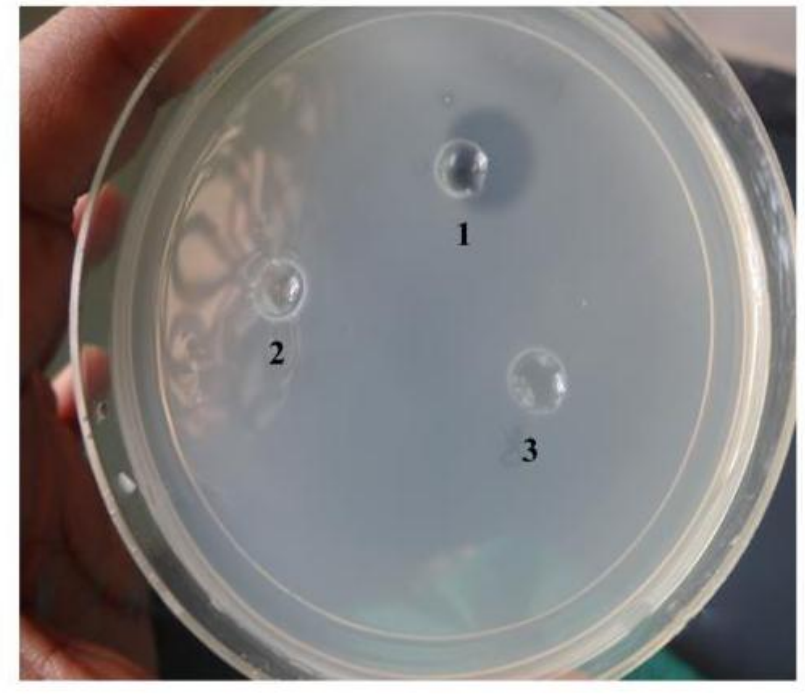

Clearance Zone of TAS broth cultures

\section{1- Unheated}

2- Heated for $8 \mathrm{~min}$

3- Heated for $16 \mathrm{~min}$

Fig.8 Results of gelatin gel test
a. Presence of thermostable proteases
b. Presence of Thermolabile proteases

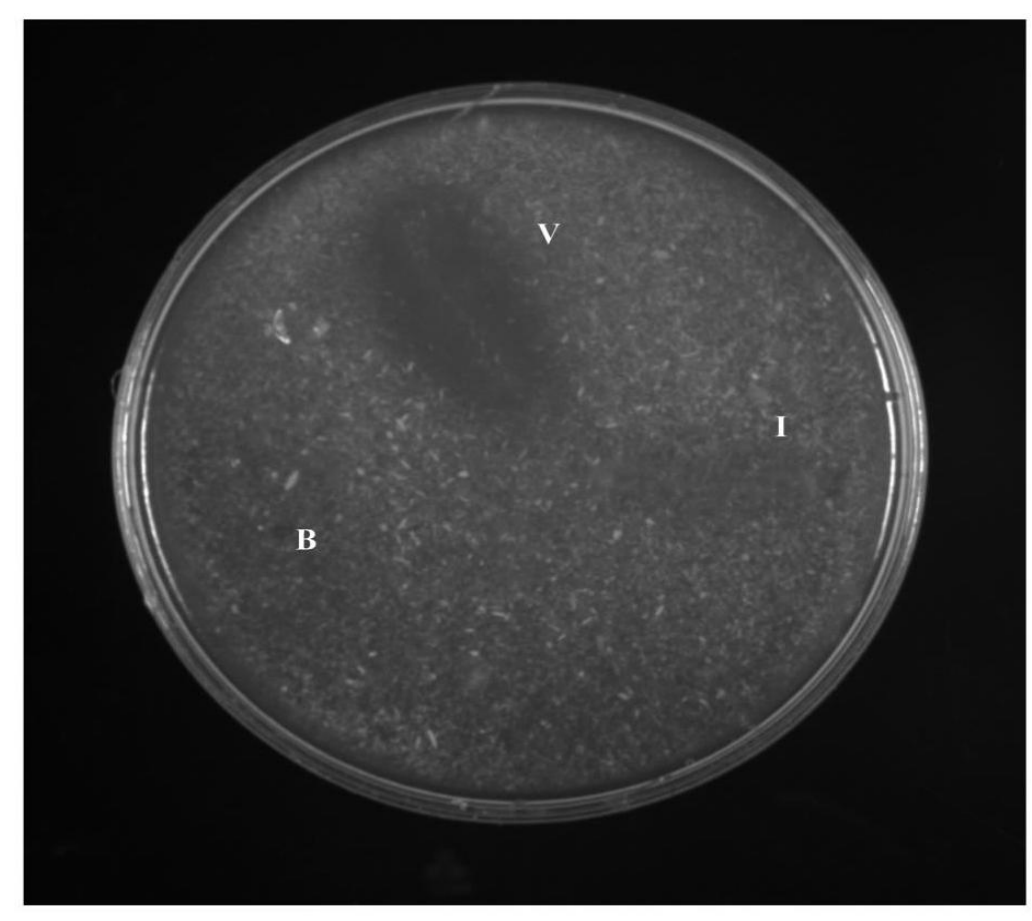

Zone of hydrolysis of Elastin

V-Virulent Strains ( $>7$ days)

I- Intermediate Strains (7-14 days)

B-Benign Strains ( $>21$ days)

Fig.9 Results of elastase test 
In the present study gelatin gel test and elastase test were used to study the virulence of D.nodosus isolates. Gelatin gel test revealed that $53 \%$ of the isolates were found to be virulent followed by $33 \%$ of the strains are intermediate and $14 \%$ of the strains are benign. Whereas the elastase test performed on the same isolates, $13 \%$ of isolates are found to be virulent, $13 \%$ isolates are found to be intermediate and $13 \%$ isolates found to be benign. Whereas the rest of $61 \%$ isolates did not exhibit any elastase activity. Similar results were reported by Palmer, (1993) and Liu et al., (1993).

Egerton et al., (2000) and Stewart (1989) stated that the phenotypic expression of D.nodosus is often influenced by factors that affect the growth and viability of the bacteria such as seasonal and local conditions. According to Liu et al., (1994) the diagnostic test based on the measurement of phenotypic characterization of D.nodosus are variable with factors and conditions that affect the growth of these bacteria. In addition a slight change of the conditions in these tests might also cause some variation in test results like the usage of different brands and batches of elastin might also has a bearing on the results of elastase test.

The D.nodosus isolates defined as virulent by Gelatin gel test belongs to four different serogroups. Whereas the intermediate and benign strains belonged to two serogrups only. The greater serogroup diversity of virulent isolates indicates a greater genetic variation among virulent variants. These results were completely contradictory to the results reported by Gilhus et al., (2013) in Norway where the greater serogroup diversity is seen in benign strains which belongs to eight different serogroups. The agreement between elastase test and the gelatin test did not tally in the present study. There is a difference in the number of isolates proved to be virulent in Gelatin gel test (53\%) and
Elastase test (13\%). Similarly with intermediate in Gelatin gel test (33\%) and elastase test $(13 \%)$. However there is slight correlation with benign strains of $13 \%$ each. $61 \%$ of isolates did not show any activity of elastase.

Links and Morris, (1996) and Gillhus et al., (2013) worked on the similar lines and reported that there is agreement between elastase test and Gelatin gel test. The difference in agreement between GG test and elastase test in the present study may be that the isolates produced a thermostable protease which is different from elastase. Dichelobacter nodosus produces different types of proteases like gelatinase, fibrogenase, collagenase, caesinase and elastase (Egerton, 2000; Kortt et al., 1994). Kennan et al., 2001 reported that the analysis of mutants of extracellular protease genes has shown that AprV2 thermostable protease is responsible for extracellular protease activity. AprV2 gene codes for elastases.

This difference in the proteases secreted by the local isolates might be the reason for existence of strains of D.nodosus in tropical climates where the temperature may reach to $47^{\circ} \mathrm{C}$ in summer which was reported earlier by Sreenivasulu et al., (2012). It is also possible that changes in protease thermostability are due to a conformational change in the protein and is not a genetic abnormality, or is not one that can be detected by the typing methods used here. Previous work has indicated that the difference between a protease (V2) from a virulent isolate and a protease (B2) from a benign isolate was due to a single amino acid change. It was hypothesised that the protease genes may have diverged from a common ancestral gene (Riffkin et al., 1995).

Other researchers suggest that the isoenzyme bands arise from three or four closely-related genes that code for protease (Moses et al., 
1995). Stauble et al., (2014) developed a competitive real time PCR for detection and demonstration of virulent and benign D.nodosus targeting AprV2 and BprV2 which is a rapid and sensitive diagnostic tool for the early detection and virulotyping of D.nodosus directly from simple, non-invasive interdigital swabs of sheep. Locher et al., (2015) stated that the competitive PCR developed for detection of AprV2/B2 genes of D.nodosus will be very useful for nationwide fotrot control programme.

\section{References}

Egerton J R 2000 In Diseases of Sheep, 3rd edition. Martin, W. B. and Aitken, I.D (Editors). Blackwell Science. Pp 243 248.

Gilhuus M, Vatn S, Dhungyel O P, Tesfamichael B, Abee-lund and $\mathrm{T} \mathrm{M}$ Jorgensen H J 2013 Characterization of Dichelobacter nodosus isolates from Norway. Veterinary Microbiology 163 142-148.

Kennan R, Dhungyel, O, Whittington R, Egerton J and Rood J 2001 The type IV fimbrial subunit gene $(\operatorname{fim} \mathrm{A})$ of Dichelobacter nodosus is essential for virulence, protease secretion, and natural competence. Journal of Bacteriology 183: 4451-4458

Kortt A A, Caldwell J B, Lilley G G, Edwards R, Vaughan J and Stewart D J 1994 Characterization of a basic serine protease secreted by virulent strains of Dichelobacter nodosus and identification of a distinct, but closely related, protease secreted by benign strains. Biochemical Journal 299: 521525.

Links I J and Morris 1996 Assesment of gelatin gel and elastase tests for detection of protease activity of Dichelobacter nodosus isolates from ovine footrot. Veterinary Microbiology
51305-318.

Liu D and Yong, W K 1993 Dichelobacter nodosus: differentiation of virulent and benign strains by gene probe based dot blot hybridisation. Vet. Microbiol., 38: 71-79.

Liu D, Roycroft C, Samuel J and Webber J 1994 A retrospective study of clinical and laboratory characteristics of ovine footrot. Veterinary Microbiology 42:373-381.

Locher I, Greber D, Holdener K, Luchinger R, Haerdi-Landerer C, SchupbachRegula G, Frey J, Steiner A. 2015. Longitudinal Dichelobacter nodosus status in 9 sheep flocks free from clinical footrot. Small Rumin Res 132:128 -132.

https://doi.org/10.1016/j.smallrumres.20 15.10.02

Moses, E K., Good, R T., Sinistaj, M., Billington, S J., Langford, C J. and Rood, J I. (1995). A multiple sitespecific DNA-inversion model for the control of Omp1 phase and Antigenic variation in Dichelobacter nodosus. Mol. Microbiol., 17: 183-196.

Palmer MA. 1993. A gelatin test to detect activity and stability of proteases produced by Dichelobacter nodosus. Veterinary Microbiology 36: 113-122

Riffkin M C, Wang L F, Kortt A A and Stewart D J 1995 A single amino-acid change between the antigenically different extracellular serine proteases V2 and B2 from Dichelobacter nodosus. Gene, 167: 279-283.

Sreenivasulu D, Vijayalakshmi S, Raniprameela D, Karthik A, Wani S A and Hussaian I 2013 Prevalence of ovine footrot in the tropical climate of southern India and isolation and characterization of Dichelobacter nodosus. Rev.Sci.Tech.Off.Int.Epiz, OIE 32(3).

Stauble A, Steiner A, Frey J, Kuhnert P. 2014. 
Simultaneous detection and discrimination of virulent and benign Dichelobacter nodosus in sheep of flocks affected by foot rot and in clinically healthy flocks by competitive real-time PCR. J Clin Microbiol 52:1228 -1231. https://doi.org/10.1128/ JCM.03485-13.

Stewart D J 1979 The role of elastase in the differentiation of Bacteroides nodosus infections in sheep and cattle. Research in Veterinary Science 27: 99-105.

Stewart D J 1989 Footrot of sheep. In: Egerton, J.R., Yong, W.K. and Riffkin, G.G. (Eds.), Footrot and Foot Abscess of Ruminants, 1st ed. CRC Press, Boca Raton.

Wani S A, Samanta I and Kawoosa S 2007. Isolation and characterization of Dichelobacter nodosus from ovine and caprine footrot in Kashmir, India. Research in Veterinary Science 83: 141144.

Wani S A, Samanta I, Bhat M A and Buchh A S 2004 Molecular detection and characterization of Dichelobacter nodosus in ovine footrot in India. Molecular and cellular probes 18: 289 $-291$.

\section{How to cite this article:}

Vijayalakshmi, S., D. Sreenivasulu, D. Raniprameela, N. Vinodkumar and Karthik, A. 2020. Phenotypic Virulence Characterization of Dichelobacter nodosus from the Cases of Ovine Footrot in Andhra Pradesh and Telangana states of India. Int.J.Curr.Microbiol.App.Sci. 9(06): 2924-2936. doi: https://doi.org/10.20546/ijcmas.2020.906.352 